\title{
Ricotta whey supplemented with gelatin and collagen for the encapsulation of probiotic lactic acid bacteria
}

\author{
Gabriela Rabaioli RAMA ${ }^{1,2 \#, ~ D a n i e l a ~ D U L L I U S ~}{ }^{1 *}$, Wendell Dall AGNOL ${ }^{1}$, Vanessa Mendonça ESQUERDO ${ }^{3}$, \\ Daniel Neutzling LEHN ${ }^{1}$, Claucia Fernanda Volken de SOUZA ${ }^{1,2 *}$ (i)
}

\begin{abstract}
The aim of the present study was to evaluate the viability of probiotic bacteria Lactobacillus acidophilus (LA-5) ${ }^{\circledR}$ and Bifidobacterium lactis (BB-12) ${ }^{\circledR}$ encapsulation using spray drying (SD) with ricotta whey supplemented with gelatin and hydrolyzed collagen as encapsulating material. Following previous experiments, these gelatin:collagen ratios were defined: 7:3 (gelatin:collagen) for L. acidophilus LA-5 and 9:1 for B. lactis BB-12, which had reduced bacterial counts of 0.46 and 1.26 log Colony-Forming Units (CFU)/g, respectively. There was a viability loss of $0.70 \log \mathrm{CFU} / \mathrm{g}$ and $0.34 \log \mathrm{CFU} / \mathrm{g}$ for LA-5 and BB-12, respectively, throughout storage $\left(30\right.$ days, $\left.25^{\circ} \mathrm{C}\right)$. When exposed to the simulated gastric juice, encapsulated LA-5 and BB-12 had higher survival rates ( 89.91 and $95.83 \%$, respectively) than non-encapsulated microorganisms under the same conditions (54.78 and $57.27 \%$, respectively). In the presence of bile salts, encapsulated LA-5 and BB-12 had survival of $77.44 \%$ and $51.05 \%$, respectively, while free cells showed rates of over 99\%. After 30 days, these rates decreased to 71.07 and 50.60\%, for encapsulated LA-5 and BB-12, respectively. Therefore, ricotta whey associated to gelatin and hydrolyzed collagen can be considered a potential encapsulating agent for the SD of probiotic dairy bacteria.
\end{abstract}

Keywords: encapsulation; dairy whey; spray drying; gastrointestinal tract.

Practical Application: This study uses an important dairy industry waste product, ricotta whey, for the encapsulation of dairy bacteria through spray drying. This waste is produced at a large scale and has high polluting potential if discarded inappropriately; therefore, strategies for reusing it are essential. On the other hand, spray drying is reported as the best cost-benefit method to obtain powdered lactic cultures, with several advantages compared to other techniques such as lyophilization.

\section{Introduction}

Probiotics have a beneficial effect on human gut microbiota via antagonistic effects, competition for nutrients, and immune effects, rendering the organisms more resistant to pathogens (Chugh \& Kamal-Eldin, 2020; Puupponen-Pimiä et al., 2002). New approaches differentiate probiotic microorganisms into 'true probiotics' (TP, when these cells are viable and active), 'pseudo-probiotics' (PP, when the cells are viable but inactive, or in vegetative or spore forms $\left(\mathrm{PP}_{\mathrm{V}}\right.$ or $\left.\left.\mathrm{PP}_{\mathrm{S}}\right)\right)$, and finally, as 'ghost probiotics' (GP, when cells are non-viable, either intact or ruptured $\left(\mathrm{GP}_{\mathrm{I}}\right.$ or $\left.\mathrm{GP}_{\mathrm{R}}\right)$ ) (Barros et al., 2020; Zendeboodi et al., 2020). The major probiotic bacterial genera are Lactobacillus and Bifidobacterium, which are largely used acid-lactic bacteria (Brinques et al., 2010; Rokka \& Rantamäki, 2010) in the food industry, as they provide differentiated flavor and scent aside from probiotic effects (L. Li \& Han, 2018). Some strains may also provide texture improvements (Guimarães et al., 2020), and even mitigate toxic compounds in food products (Khorshidian et al., 2020). Probiotic microorganisms are mostly incorporated in dairy products such as yoghurts and fermented milk (Alizadeh Khaledabad et al., 2020; Lucatto et al., 2020; Sarfraz et al., 2019; Shafi et al., 2019), which is why they must be resistant to the presence of oxygen and high temperatures, conditions that are typical in food processing (Fernández et al., 2015; Motta \& Gomes, 2015).

Additionally, low survival rate in the gastrointestinal tract (GIT) due to acid $\mathrm{pH}$ and high concentrations of bile salts reduces the potential application of the free form of these microorganisms in foods. In this regard, encapsulation can add a protection barrier to probiotic bacteria sensitive to adverse conditions, increasing their survival rates when going through the GIT and their viability when incorporated to food products (De Castro-Cislaghi et al., 2012; Peighambardoust et al., 2011; Roobab et al., 2020). Moreover, encapsulation of probiotics enable their controlled release into certain media, prolonging their beneficial effects (Ilha et al., 2015; Khem et al., 2016b). Among the encapsulation methods, atomization (spray drying, $\mathrm{SD}$ ) is one of the most frequently employed due to its cost benefit ratio (Pérez-Chabela et al., 2013). The SD technique produces capsules comprised of a core (containing the microorganisms) surrounded by encapsulating agents (wall material), forming particles of sizes that range from millimeters to nanometers (Đorđević et al., 2014). 
Stability of the encapsulated material (core) is directly related to the nature of the wall material. Many materials can be used to encapsulate and protect bioactive substances, e.g. polysaccharides such as Arabic gum, starch, alginate, carrageenan, and chitosan, which are largely used in the encapsulation of microorganisms (Bustos \& Bórquez, 2013; Eckert et al., 2018; Khem et al., 2016a). According to Maciel et al. (2014), the combination of carbohydrates with proteins is essential to form resistant capsules, due to the emulsifying property of protein-based material, which thus allows the formation of resistant films. Gelatin and hydrolyzed collagen are the most frequently used proteins due to their gelation properties, as well as their biocompatibility, and non-toxicity (Li et al., 2009). Moreover, these compounds are considered inexpensive and biodegradable protein sources (Gómez-Guillén et al., 2011).

Aside from gelatin and hydrolyzed collagen, dairy whey proteins are also promising encapsulating material for probiotics (Abd El-Salam \& El-Shibiny, 2015). Cheese whey is a by-product rich in carbohydrates and proteins, obtained from the coagulation of milk proteins in cheese manufacture. This by-product can be used in the production of ricotta; however, this process generates another by-product called ricotta whey (Sansonetti et al., 2009). These materials are produced at a large scale, and approximately 230 million tons of cheese whey are estimated to be produced worldwide in 2023 (Rama et al., 2019). If cheese whey is discarded inadequately into the environment, it might cause environmental problems due to its large volume and high organic matter content. Reuse of dairy whey has been studied in order to find applications that lead to lower amounts of waste to be treated. Considering the nutritional composition and high treatment cost of cheese whey and whey permeate (Mollea et al., 2013), technologies and new applications are sought to use these by-products, e.g. as ingredients for the formulation of different dairy products (Fangmeier et al., 2019; Guimarães et al., 2018, 2019; Monteiro et al., 2018, 2020; Trindade et al., 2019).

Ricotta cheese yield is approximately $4.5 \mathrm{~kg} / 100 \mathrm{~L}$, which means that $95.5 \mathrm{~L}$ of ricotta whey are released for every $100 \mathrm{~L}$ of cheese whey (Knorr Valadão et al., 2016). Studies indicate that $25 \%$ ( 45 million tons per year) of all processed cheese whey in the world is transformed into ricotta cheese (Smithers, 2015). By combining these data, it is possible to estimate that approximately 43 million tons of ricotta whey are produced every year, with little or no use for the industry. As it is rich in lactose, ricotta whey combined with the proteins in gelatin and hydrolyzed collagen becomes an alternative for the production of capsules containing probiotic bacteria.

Ricotta whey, as opposed to cheese whey, has not been widely tested as encapsulating agent for the SD of microorganisms, yet. Therefore, the aim of the present study was to evaluate the viability of SD encapsulation of probiotic bacteria Lactobacillus acidophilus (LA-5) ${ }^{\circledR}$ and Bifidobacterium lactis (BB-12) ${ }^{\circledR}$ using ricotta whey supplemented with gelatin and hydrolyzed collagen as wall materials. For that purpose, the viability of microorganisms was evaluated before and after SD, and during a storage period of 30 days at $25^{\circ} \mathrm{C}$. Survival rate of both encapsulated and free bacteria under simulated gastrointestinal and intestinal tract conditions was also evaluated.

\section{Materials and methods}

\subsection{Material}

Ricotta whey, in natura, was donated by a dairy factory from the Taquari Valley region, RS, Brazil. Physicochemical parameters were analyzed according to AOAC International (Association of Official Analytical Chemists, 2012). Total solids were evaluated using an oven dryer at $105{ }^{\circ} \mathrm{C}(\operatorname{method}$ No. 990.20), ash was evaluated using a muffle furnace at $550^{\circ} \mathrm{C}$ (method No. 968.08), fat was evaluated using the Mojonnier method (No. 2000.18) (Association of Official Analytical Chemists, 2012), and protein was evaluated using the Kjeldahl method (No. 991.20) (Association of Official Analytical Chemists, 2012). Lactose content was evaluated using the dinitrosalicylic acid (DNS) method (Miller, 1959). The commercial lactic bacteria L. acidophilus (LA-5) ${ }^{\circledR}$ and B. lactis (BB-12) ${ }^{\circledR}$ used in this study were acquired from Chr. Hansen (Valinhos, São Paulo, Brazil). Cofiber Heg 60 collagen was acquired from Luchebras ${ }^{\circledR}$ (Cachoeirinha, RS, Brazil) and gelatin was acquired from Ferga ${ }^{\circledR}$ (Novo Hamburgo, RS, Brazil). All chemical products, reagents, and culture media were acquired from either Merck (KGaA, Darmstadt, Germany) or Sigma-Aldrich (St. Louis, MO, USA).

\subsection{Preparation of microorganisms and encapsulating agent solutions}

Stored in $20 \%$ glycerol at $-20{ }^{\circ} \mathrm{C}$, microorganisms were activated in De Man, Rogosa and Sharpe (MRS) broth at a 1:50 ratio (200 $\mu \mathrm{L}$ of culture to $10 \mathrm{~mL}$ MRS broth), with incubation at $37^{\circ} \mathrm{C}$ for $24 \mathrm{~h}$, without agitation. Microbial cultures were transferred (using drop plate technique) from that broth to Petri dishes containing MRS agar, which were incubated at $37^{\circ} \mathrm{C}$ for $24 \mathrm{~h}$, and then, maintained under refrigeration. For encapsulation experiments, colonies isolated from these dishes were transferred to $50 \mathrm{~mL}$ of MRS broth, with incubation at $37^{\circ} \mathrm{C}$ for $24 \mathrm{~h}$. After that, microbial cultivations were centrifuged $\left(2790 \times g, 10 \mathrm{~min}, 4^{\circ} \mathrm{C}\right)$ and the cells were rinsed according to De Prisco et al. (2015). L. acidophilus (LA-5) ${ }^{\circledR}$ and B. lactis $(\mathrm{BB}-12)^{\circledR}$ were prepared using the same method.

To prepare encapsulating solutions, the encapsulating agents, gelatin and hydrolyzed collagen, were weighed and mixed with ricotta whey. Three ratios of both materials were evaluated: $9 \%$ gelatin $(\mathrm{w} / \mathrm{w})$ and $1 \%$ collagen $(\mathrm{w} / \mathrm{w}) ; 7 \%$ gelatin $(\mathrm{w} / \mathrm{w})$ and $3 \%$ collagen $(\mathrm{w} / \mathrm{w})$; and $5 \%$ gelatin $(\mathrm{w} / \mathrm{w})$ and $5 \%$ collagen $(\mathrm{w} / \mathrm{w})$. After that, solutions underwent slow bath pasteurization at $65{ }^{\circ} \mathrm{C}$ for 30 minutes and were cooled until they reached room temperature, and subsequently, the previously prepared microorganisms were added. Probiotics LA-5 and BB-12 were added individually to each of the three encapsulating solutions (feeding solution concentration: $10^{9} \mathrm{CFU} / \mathrm{mL}$ ), totaling six different combinations of microorganisms and encapsulating agents that underwent SD encapsulation. Therefore, all final solutions contained $0.1 \mathrm{~g}$ of the encapsulating agent mixture per $\mathrm{mL}$ of ricotta whey (in ratio 9:1, it means $0.09 \mathrm{~g}$ of gelatin and $0.01 \mathrm{~g}$ of collagen per $\mathrm{mL}$, whereas in 7:1 it means $0.07 \mathrm{~g}$ of gelatin and $0.03 \mathrm{~g}$ of collagen, and so on). 


\subsection{Spray-drying encapsulation of microorganisms}

Encapsulation was performed using a spray-dryer (MSD 0.5, LabMaq, Brazil), using a $0.7 \mathrm{~mm}$ dual-fluid atomizer nozzle, and inlet and outlet temperatures of 90 and $75^{\circ} \mathrm{C}$, respectively. Feeding solution was introduced through a peristaltic pump until the drying chamber, with feeding flow of $4.5 \mathrm{~mL} / \mathrm{min}$, drying air flow of $2.5 \times 10^{6} \mathrm{~mL} / \mathrm{min}$, and compressor air pressure at $0.3 \mathrm{MPa}$, according to Eckert et al. (2017). Encapsulated microorganisms were retrieved and stored in sterile flasks at $25^{\circ} \mathrm{C}$.

\subsection{Viability of microorganisms under spray drying encapsulation conditions}

Drop plating was performed in MRS agar, adapted from Kim et al. (2008), in order to define the combinations of wall materials based on viability of microorganisms before and after encapsulation. Thus, before encapsulation, a $1-\mathrm{mL}$ aliquot was removed from the feeding solution, diluted in $0.1 \%(\mathrm{w} / \mathrm{v})$ peptone water, and plated in MRS agar. For encapsulated microorganisms, $0.1 \mathrm{~g}$ of the powder was weighed and added to $9.9 \mathrm{~mL}$ of phosphate

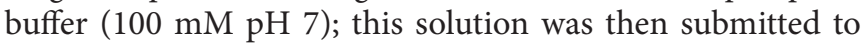
orbital agitation at $200 \mathrm{rpm}$ for $10 \mathrm{~min}$ at $20^{\circ} \mathrm{C}$ to break capsules. Afterwards, samples underwent serial dilution with $0.1 \%(\mathrm{w} / \mathrm{v})$ peptone water and subsequent drop plating in Petri dishes containing MRS agar. Reduction in microbial concentration after encapsulation was determined and expressed in log terms using Equation 1, where $\mathrm{N}_{\mathrm{b}}$ is viable cell count $(\log \mathrm{CFU} / \mathrm{g}$ ) before SD and $\mathrm{N}_{\mathrm{a}}$ is viable cell count $(\log \mathrm{CFU} / \mathrm{g})$ after SD.

$\log$ reduction $=\log \mathrm{N}_{\mathrm{b}}-\log \mathrm{N}_{\mathrm{a}}$

Comparing the reduction in amount of viable cells after SD using the different concentrations of wall materials, the most suitable gelatin/collagen ratio was chosen for each lactic bacterium evaluated. After that, SD was repeated with LA-5 and BB-12 using this ratio of encapsulating agents with the same preparation and under the same encapsulation conditions described in Sections 2.2 and 2.3, respectively.

\subsection{Viability of encapsulated microorganisms under storage conditions}

Viability of encapsulated LA-5 and BB-12 with the previously defined ratios of wall materials was evaluated at 0 and 30 days of storage at $25{ }^{\circ} \mathrm{C}$, following the methodology described in Section 2.4 and the resulting counts of viable microbial cells were expressed in $\mathrm{CFU} / \mathrm{g}$.

\subsection{Viability of encapsulated microorganisms under simulated gastric and intestinal tracts}

These assays are based on the methods published by Meira et al. (2012). Survival rate going through simulated gastric and intestinal tracts was determined for encapsulated LA- 5 and BB- 12 using the previously defined ratios of wall materials. This evaluation was conducted at 0 and 30 days of storage at $25^{\circ} \mathrm{C}$. Simulated gastric juice was prepared with $3 \mathrm{mg} / \mathrm{mL}$ pepsin in a solution of $5 \mathrm{~g} / \mathrm{L}$ $\mathrm{NaCl}$, adding hydrochloric acid $(\mathrm{HCl})$ for acidification up to
$\mathrm{pH}$ of 2, 2.5, and 3. For simulated intestinal juice, a solution containing $5 \mathrm{~g} / \mathrm{L} \mathrm{NaCl}$ and $1 \mathrm{mg} / \mathrm{mL}$ pancreatin with $\mathrm{pH} 8$ was prepared with and without bile salts at a concentration of $0.5 \%$ $\mathrm{w} / \mathrm{v}$ (1:1 mixture of sodium cholate and sodium deoxycholate). Solutions were sterilized by filtering with $0.22 \mu \mathrm{m}$-pore membrane.

For this evaluation, $0.1 \mathrm{~g}$ of each encapsulated microorganism was exposed to each gastric and intestinal tract condition: simulated gastric tract at $\mathrm{pH} 2,2.5$, and 3 ; and simulated intestinal juice with and without bile salts. Encapsulated microorganisms $(0.1 \mathrm{~g})$ were added to $1 \mathrm{~mL}$ of each solution and the mixture was homogenized using a tube agitator at $3800 \mathrm{rpm}$. Solutions simulating gastric and intestinal juices were incubated at $37^{\circ} \mathrm{C}$ for $180 \mathrm{~min}$ and $240 \mathrm{~min}$, respectively. After this period, $1 \mathrm{~mL}$ of each solution was removed and mixed with $9 \mathrm{~mL}$ of phosphate buffer (100 mM pH 7), and submitted to orbital agitation at $200 \mathrm{rpm}$ for 10 minutes at $20^{\circ} \mathrm{C}$ to break capsules. Afterwards, samples underwent serial dilution with $0.1 \%(\mathrm{w} / \mathrm{v})$ peptone water and subsequent drop plating in Petri dishes containing MRS agar. Survival rate (\%) of encapsulated LA-5 and BB-12 under each condition was obtained using Equation 2 (Bao et al., 2010), where $\mathrm{N}_{1}$ is viable cell count in encapsulated microorganisms after going through these simulated gastric and intestinal tract conditions and $\mathrm{N}_{0}$ is viable cell count of encapsulated microorganisms before going through these conditions.

Survival rate $(\%)=\frac{\log \mathrm{N}_{1}}{\log \mathrm{N}_{0}} \times 100$

Free LA-5 and BB-12 cells underwent the same conditions of simulated gastric and intestinal tracts. For that purpose, microbial cultivations were prepared as described in Section 2.2, and bacterial cells were resuspended in sterile phosphate buffer (10 mM, pH 7). $200 \mu \mathrm{L}$ of free-cell suspension were added to $1 \mathrm{~mL}$ of each solution of simulated gastric and intestinal juices, and the resulting solution was incubated at $37^{\circ} \mathrm{C}$ for $180 \mathrm{~min}$ and 240 minutes, respectively. Afterwards, samples underwent serial dilution with $0.1 \%(\mathrm{w} / \mathrm{v})$ peptone water and subsequent drop plating in Petri dishes containing MRS agar for the evaluation of survival rate of free microorganisms, following Equation 2.

\subsection{Statistical analysis}

All experiments and analyses were performed in triplicates. The results of mean viability of microorganisms after SD were submitted to an Analysis of Variance (Anova) followed by Tukey's Test, using BioEstat 5.3 to determine significant differences among mean values, with $\mathrm{p} \leq 0.05$.

\section{Results and discussion}

\subsection{Viability of microorganisms under spray-drying encapsulation conditions}

Ricotta whey composition was $50.63 \pm 2.40 \mathrm{~g} / \mathrm{L}$ of total solids, $3.98 \pm 0.37 \mathrm{~g} / \mathrm{L}$ of ashes, $4.99 \pm 0.53 \mathrm{~g} / \mathrm{L}$ of fats, $2.50 \pm 0.55 \mathrm{~g} / \mathrm{L}$ of proteins, and $46.17 \pm 1.04 \mathrm{~g} / \mathrm{L}$ of lactose. This composition is similar to that proposed by Sansonetti et al. (2009) and Guimarães et al. (2010). Results obtained in the evaluation of viability of microorganisms to SD encapsulation are described in Table 1 . The wall material 
Rama et al.

Table 1. Viability of LA-5 and BB-12 during spray drying encapsulation using ricotta whey supplemented with gelatin and collagen as wall material.

\begin{tabular}{|c|c|c|c|c|c|}
\hline $\begin{array}{l}\text { Gelatin:collagen } \\
\text { ratio }\end{array}$ & $\mathrm{MO}$ & $\begin{array}{c}\text { Cell concentration prior } \\
\text { to encapsulation } \\
(\log \mathrm{CFU} / \mathrm{g})\end{array}$ & $\begin{array}{c}\text { Cell concentration after } \\
\text { encapsulation } \\
(\log \text { CFU/g) }\end{array}$ & $\begin{array}{l}\text { Reduction } \\
(\log \text { CFU/g) }\end{array}$ & $\begin{array}{c}\text { Reduction percentage } \\
(\%)\end{array}$ \\
\hline \multirow{2}{*}{$9: 1$} & LA-5 & $10.66(0.04)^{\mathrm{b}}$ & $9.92(0.07)^{\mathrm{c}}$ & $0.74(0.04)^{\mathrm{a}}$ & $6.90(0.35)^{\mathrm{a}}$ \\
\hline & BB-12 & $9.89(0.00)^{\mathrm{b}}$ & $8.63(0.19)^{c}$ & $1.26(0.19)^{\mathrm{a}}$ & $12.74(1.75)^{\mathrm{a}}$ \\
\hline \multirow{2}{*}{$7: 3$} & LA-5 & $10.62(0.06)^{c}$ & $10.12(0.06)^{b}$ & $0.46(0.01)^{c}$ & $4.35(0.07)^{\mathrm{c}}$ \\
\hline & BB-12 & $9.71(0.00)^{c}$ & $8.66(0.05)^{\mathrm{b}}$ & $1.04(0.05)^{\mathrm{a}}$ & $10.73(0.48)^{\mathrm{a}}$ \\
\hline $5: 5$ & BB-12 & $10.06(0.08)^{\mathrm{a}}$ & $8.94(0.00)^{\mathrm{a}}$ & $1.12(0.08)^{\mathrm{a}}$ & $11.06(0.71)^{\mathrm{a}}$ \\
\hline
\end{tabular}

MO: microorganism. 9:1: 9\% (w/w) gelatin and 1\% (w/w) collagen; 7:3: 7\% (w/w) gelatin and 3\% (w/w) collagen; 5:5: 5\% (w/w) gelatin and 5\% (w/w) collagen. ${ }^{\mathrm{a}-\mathrm{c}} \mathrm{Mean}(\mathrm{standard}$ deviation), $\mathrm{n}=3$. Different superscript letters in the same column indicate significant difference ( $\mathrm{p} \leq 0.05$ ), according to Tukey's Test, between concentrations of encapsulating material for the same microorganism.

ratio with the lowest reduction (4.35\%) of LA- 5 was $7: 3(\mathrm{w} / \mathrm{w})$ of gelatin:collagen. Since there was no significant difference $(\mathrm{p}>0.05)$ between the three ratios of wall materials for BB-12, the ratio of encapsulating agents defined for this microorganism was the one with the lowest collagen concentration $(9: 1(\mathrm{w} / \mathrm{w}))$, because of the hygroscopic property of this protein (Gómez-Guillén et al., 2011), which could add undesirable moist to the capsules. Regardless of the ratio of encapsulating materials, LA-5 showed higher resistance to SD encapsulation than BB-12. Nunes et al. (2018) also observed higher survival rates of SD-encapsulated LA-5 (84.61\%) than BB-12 (79.73\%), using a mixture of Arabic gum, maltodextrin, glycerol, and Tween 80 . Using goat milk as encapsulating agent, Ranadheera et al. (2015) also observed that LA-5 had lower loss of viability during SD than BB-12. According to Ranadheera et al. (2015) bifidobacteria are more susceptible to high temperature than lactobacilli.

In fact, the genus Lactobacillus has been largely studied for SD encapsulation. Published studies refer to different lactobacillus species encapsulated with a wide array of wall materials, e.g. sodium alginate, skimmed milk, trealose, maltodextrin, and components derived from plants such as Aloe Vera (Ceja-Medina et al., 2020; Eckert et al., 2017; Gbassi et al., 2009; Liao et al., 2017; Tripathi \& Giri, 2014). There are also studies describing the encapsulation of Bifidobacterium species with several wall materials (De Castro-Cislaghi et al., 2012; Dianawati et al., 2013; Picot \& Lacroix, 2004; Prasanna \& Charalampopoulos, 2018). Dianawati et al. (2013) alone have studied the combination of four protein sources with three different sugars: sodium caseinate, whey protein concentrate, skimmed milk, and soy protein isolate; and glycerol, mannitol, and maltodextrin. These studies show that the encapsulation of these microorganisms is viable, even though the high temperatures in SD might hamper their survival. Therefore, the novelty in the present study is the choice of encapsulating agents to protect probiotic lactic bacteria, particularly ricotta whey, which is as highly pollutant a waste product as it is underused in the industry (Carvalho et al., 2013; Guimarães et al., 2010), unlike cheese whey, which already has several reuse alternatives cited in literature (Ahmad et al., 2019; Smithers, 2015; Trindade et al., 2019).

Consequently, choosing suitable encapsulating agents is essential to ensure that a minimum concentration of $10^{6} \mathrm{CFU} / \mathrm{mL}$ of microorganisms are viable after the SD (Food and Agriculture Organization, 2002). Gelatin and hydrolyzed collagen are protein sources, which ensure the formation of structured and resistant capsules, thus preventing them from breaking, as well as from adhering to the wall of the drying equipment (Khem et al., 2016b). Lactose, on the other hand, undergoes a phenomenon called caking during SD (Fox et al., 2015). The amorphous disaccharide absorbs water and is transformed into monohydrate crystals. In fact, lactose crystallization in SD has also been studied by Islam et al. (2013). Regarding encapsulation, the interaction between lactose and cell membranes of lactic acid bacteria has been proposed by many authors, including Ananta et al. (2005), Santivarangkna et al. (2008a, b), and Gong et al. (2014). This interaction possibly mitigates damages caused by SD and favors the viability of microorganisms during storage (Maciel et al., 2014). Those are the reasons why LA- 5 and BB- 12 had high survival rates after SD encapsulation in this study.

Salar-Behzadi et al. (2013) also encapsulated BB-12 using gelatin as encapsulating agent, having found that this material was able to protect the cell membrane of this microorganism under the adverse conditions of SD. In the same study, the authors observed that the efficiency of gelatin was similar to that of Arabic gum and pectin, and higher than that of maltodextrin and skimmed milk. Gelatin also had better results for the encapsulation of Lactobacillus sp. compared to maltodextrin and Arabic gum, allowing a higher survival than these materials after SD, by 2 and $1 \log$ CFU/g, respectively (Guergoletto et al., 2017). Regarding sugars, disaccharides other than lactose have been employed for the encapsulation of probiotic bacteria, especially trealose. Oluwaseun Sunny-Roberts \& Knorr (2011) have found that this sugar alone enables $69 \%$ of survival to L. rhamnosus $G G$, while a supplementation with monosodium glutamate increases this rate to $80 \%$. When compared to maltodextrin (an oligosaccharide), trealose was more efficient in protecting L. casei, with survival rates of $34 \%$ and $56 \%$, respectively.

\subsection{Viability of encapsulated microorganisms under storage}

After the suitable gelatin and hydrolyzed collagen ratios were defined for the SD encapsulation of LA- 5 and BB-12, these microorganisms were observed to survive under storage conditions at $25^{\circ} \mathrm{C}$ at 0 and 30 days, and these results are shown 
in Table 2. For this evaluation, LA-5 and BB-12 were encapsulated with ricotta whey supplemented, respectively, with 7:3 and 9:1 $(\mathrm{w} / \mathrm{w})$ of gelatin:collagen.

After 30 days of storage, viability loss of 0.70 and $0.34 \log \mathrm{CFU} / \mathrm{g}$ was observed for LA-5 and BB-12, respectively. On one hand, LA-5 showed a lower reduction of cell viability during SD encapsulation, which is possibly due to the higher resistance of lactobacilli to high temperatures compared to bifidobacteria (Ranadheera et al., 2015). $\mathrm{BB}-12$, on the other hand, had a lower viability reduction during 30 days of storage at $25{ }^{\circ} \mathrm{C}$. Therefore, Khem et al. (2016b) theorized that the survival of encapsulated microorganisms might be linked to the adhesion of cells to the protein core of capsules, via hydrophobic bonds. Therefore, denatured proteins have a higher potential for interacting with bacterial cells due to the decompaction of their globular structure and the consequent exposure of reactive groups, providing higher protection to bacterial cells. Considering that gelatin is the denatured form of collagen (Wang et al., 2016), it is possible that BB-12 benefitted from the higher concentration of this protein component it its capsules, and that is why it might have maintained higher viability throughout the 30 days of storage at $25^{\circ} \mathrm{C}$.

De Castro-Cislaghi et al. (2012) obtained constant viability of encapsulated BB-12 throughout 120 days of storage at $4{ }^{\circ} \mathrm{C}$. Actually, storage at higher temperatures, such as the one used in the present study $\left(25^{\circ} \mathrm{C}\right)$ causes higher loss of microbial viability (Golowczyc et al., 2011). This was also observed by Huang et al. (2017), who performed SD of Lactobacillus casei BL23 using cheese whey as wall material, and compared the effects of storage at 4 and $25^{\circ} \mathrm{C}$ on the viability of this encapsulated microorganism. The authors observed that $L$. casei population remained stable throughout the first two months of storage at $4{ }^{\circ} \mathrm{C}$, while there already was reduction in the first 7 days at a higher temperature. By the end of 30 days, L. casei had a reduction of $2 \log \mathrm{CFU} / \mathrm{g}$ during storage at $25^{\circ} \mathrm{C}$. Therefore, both encapsulated LA-5 and BB-12 had better viability results during storage than those studied by Huang et al. (2017), which is possibly related to the fact that we used gelatin and hydrolyzed collagen to supplement dairy whey in its protective action. When exposed to heat in $\mathrm{SD}$, proteins present in these materials denature, causing a higher interaction with the lactose from ricotta whey, and consequently, with cell membrane components; this, according to Maciel et al. (2014), provides higher protection to microorganisms. Additionally, the characteristics of lactic bacterial strains used here might have affected resistance to stressful conditions, since certain bacterial species have already been observed to be more resistant than others to a series of adverse conditions (Ferrando et al., 2016; Huang et al., 2018; Lavari et al., 2015).

Table 2. Viability (in CFU/g) of encapsulated LA-5 and BB-12 with ricotta whey supplemented with gelatin and collagen, after 0 and 30 days of storage at $25^{\circ} \mathrm{C}$.

\begin{tabular}{cccc}
\hline $\begin{array}{c}\text { Gelatin:collagen } \\
\text { ratio }\end{array}$ & Microorganism & $\begin{array}{c}\text { Viability at } \\
\text { time zero } \\
(\mathrm{CFU} / \mathrm{g})\end{array}$ & $\begin{array}{c}\text { Viability } \\
\text { after 30 days } \\
(\mathrm{CFU} / \mathrm{g})\end{array}$ \\
\hline $7: 3$ & LA-5 & $7.60 \times 10^{9}$ & $1.50 \times 10^{9}$ \\
$9: 1$ & BB-12 & $5.60 \times 10^{8}$ & $2.55 \times 10^{8}$ \\
\hline
\end{tabular}

\subsection{Viability of encapsulated microorganisms under simulated gastric and intestinal tracts}

Concentrations of viable LA- 5 and BB- 12 cells encapsulated with ricotta whey supplemented with 7:3 and 9:1 (w/w) of gelatin:collagen, respectively, at 9 and 30 days of storage at $25^{\circ} \mathrm{C}$ are shown in Figure 1, after undergoing simulated gastric $(\mathrm{pH} 2$, 2.5, and 3) and intestinal tract conditions (with and without bile salts). In the evaluation of simulated gastric tract, the concentration of viable cells of both microorganisms was higher than $8 \mathrm{log}$ $\mathrm{CFU} / \mathrm{g}$ in both periods evaluated, which is a concentration higher to the recommended by the Food and Agriculture Organization and the World Health Organization (Food and Agriculture Organization, 2002). Furthermore, the presence of pepsin $(3 \mathrm{mg} / \mathrm{mL})$ and low $\mathrm{pH}$ (2.0 to 3.0) did not significantly affect survival of the encapsulated microorganisms, which is a relevant result, considering that resistance of probiotics to these conditions is critical for their activity in the human organism (Del Piano et al., 2011; Tripathi \& Giri, 2014). When going through simulated intestinal tract conditions, however, the reductions in the viability of both encapsulated microorganisms were more significant in the presence of bile salts $(0.5 \% \mathrm{w} / \mathrm{v})$. At 0 days of storage, survival rates of LA-5 and BB-12 were 77.44 and $51.05 \%$, respectively, and after 30 days, these values were 71.07 and $50.60 \%$.

Comparing encapsulated and non-encapsulated probiotic lactic bacteria (Figure 2), encapsulated LA-5 and BB-12 had higher survival going through the gastric tract than non-encapsulated microorganisms. Under the most extreme gastric condition ( $\mathrm{pH} 2$ ), LA-5 and BB-12 survived at rates of 89.81 and $95.83 \%$, respectively, while free bacteria had survival rates of 54.78 and $57.27 \%$. Importantly, BB-12 had higher tolerance to all simulated gastric tract conditions, and it therefore had higher survival rates, which might be considered a characteristic of the strain. These results emphasize the importance of encapsulation to maintain the viability of probiotics in the gastric tract. Figure 2 also shows similar survival rates of LA-5 in the presence of bile salts, as the survival of the free cells of this bacterium was $81.55 \%$. Free BB-12 microorganisms had a survival rate of $89.22 \%$ under the same condition, which is higher than BB-12 encapsulated with ricotta whey supplemented with 9:1 (w/w) of gelatin:collagen (51.05\%). However, in the absence of bile salts (with only $1 \mathrm{mg} / \mathrm{mL}$ of pancreatin), survival rates remained higher than $89 \%$ in both free and encapsulated LA-5 and BB-12. This was also observed by Eckert et al. (2017) and Huang et al. (2017), and corroborated by Ding \& Shah (2007, 2009), who state that probiotic bacteria are sensitive to bile salts, especially at concentrations of $0.5 \%(\mathrm{w} / \mathrm{v})$ or higher.

These salts are in fact polarized steroids that play an important role in absorbing fat in the intestines, especially through the mechanism of micelle formation (Bodewes et al., 2015). Therefore, bile salts have the ability to imbalance the fat-aqueous interface of molecules, and therefore, displace proteins, peptides, and other active compounds in food products (Euston et al., 2013; Maldonado-Valderrama et al., 2011). These salts also have powerful antimicrobial effects (Bruno, 2012; Sannasiddappa et al., 2017). Following this logic, encapsulated bacteria already undergo stressful conditions during SD, as its inactivation mechanisms are driven by either dehydration or high temperatures (Gong et al., 2014). 

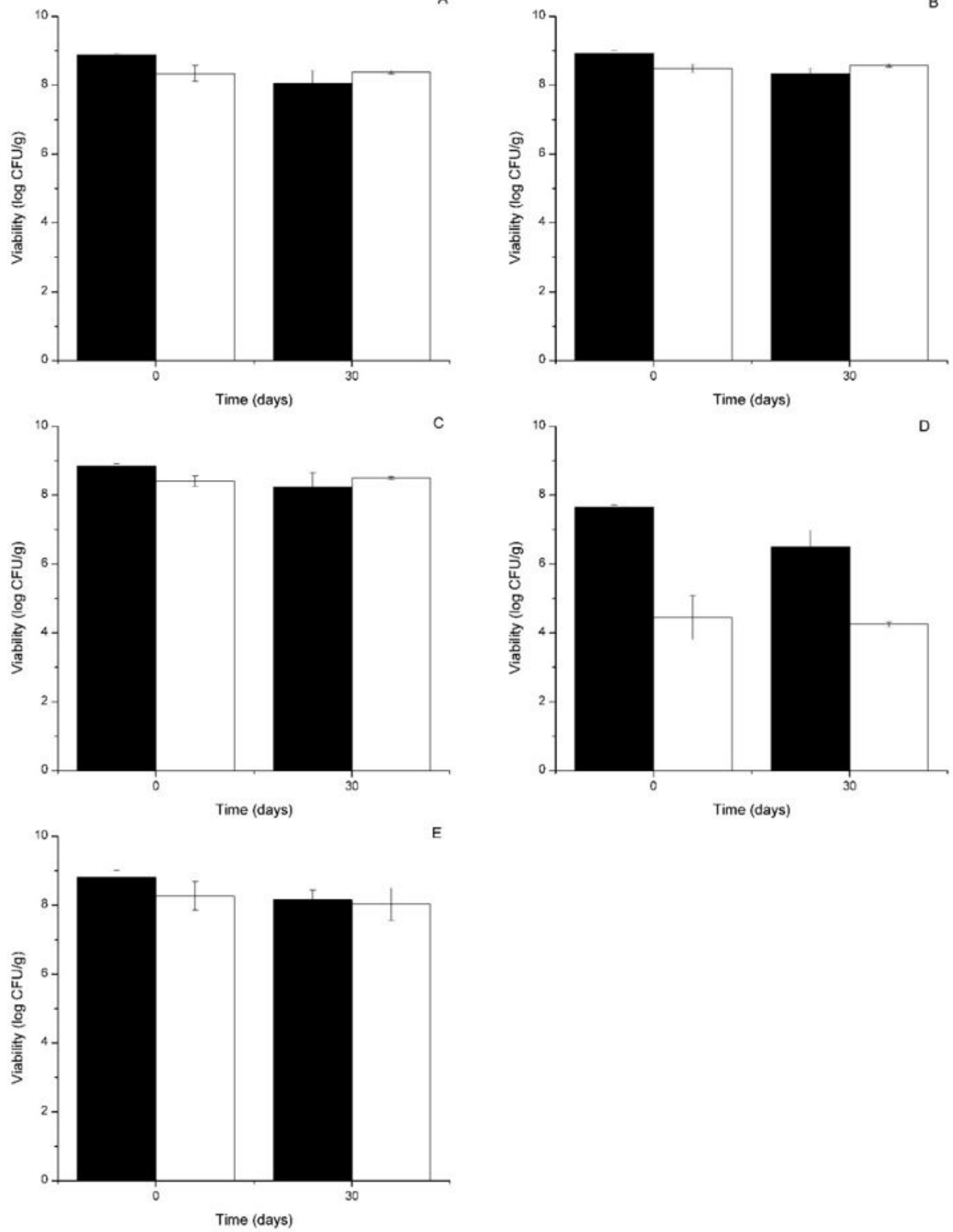

Figure 1. Viability (in log CFU/g) of LA-5 (black bars) encapsulated with ricotta whey supplemented with gelatin and collagen (7:3, w/w) and BB-12 (white bars) encapsulated with ricotta whey supplemented with gelatin and collagen $(9: 1, \mathrm{w} / \mathrm{w})$ after going through simulated gastric and intestinal tracts, at 0 and 30 days of storage at $25^{\circ} \mathrm{C}$ under the following conditions: (A) pH 2; (B) $\mathrm{pH} 2.5$; (C) pH 3; (D) with bile salts; and (E) without bile salts. 

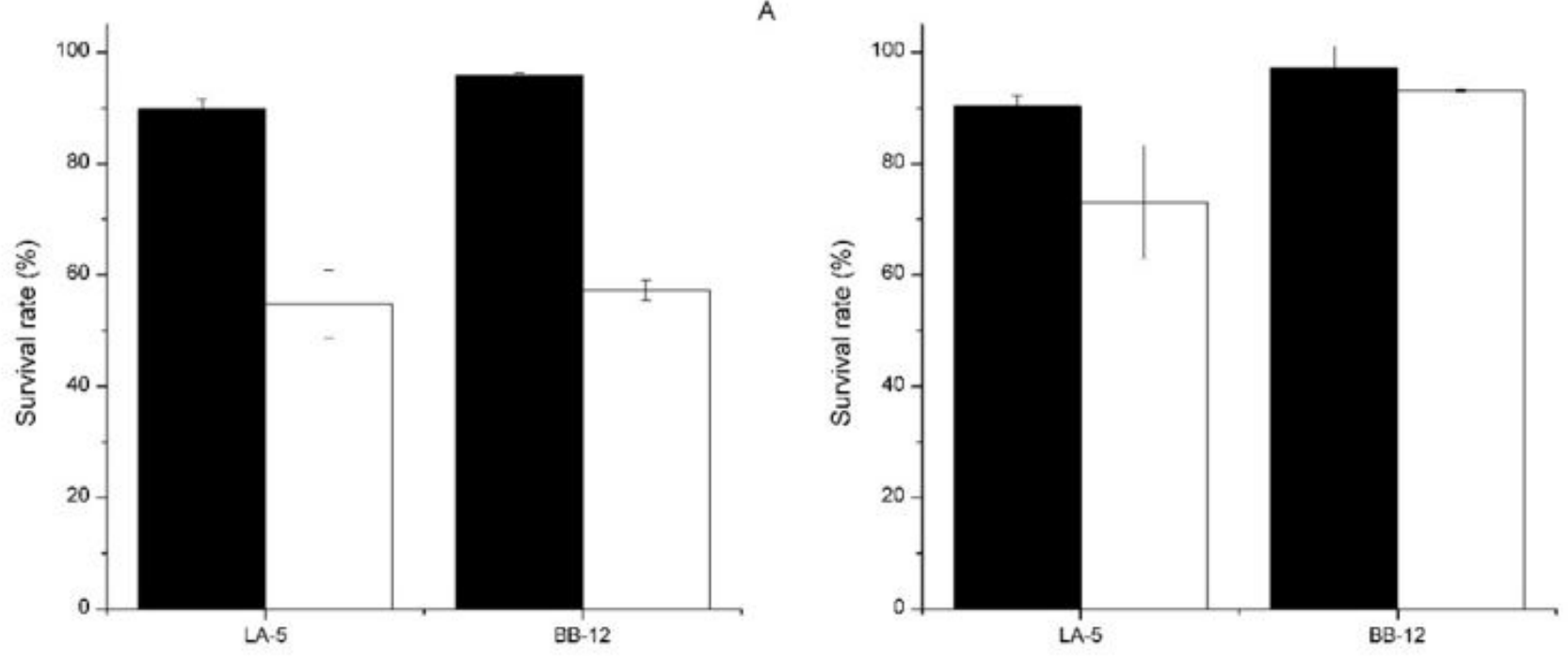

C
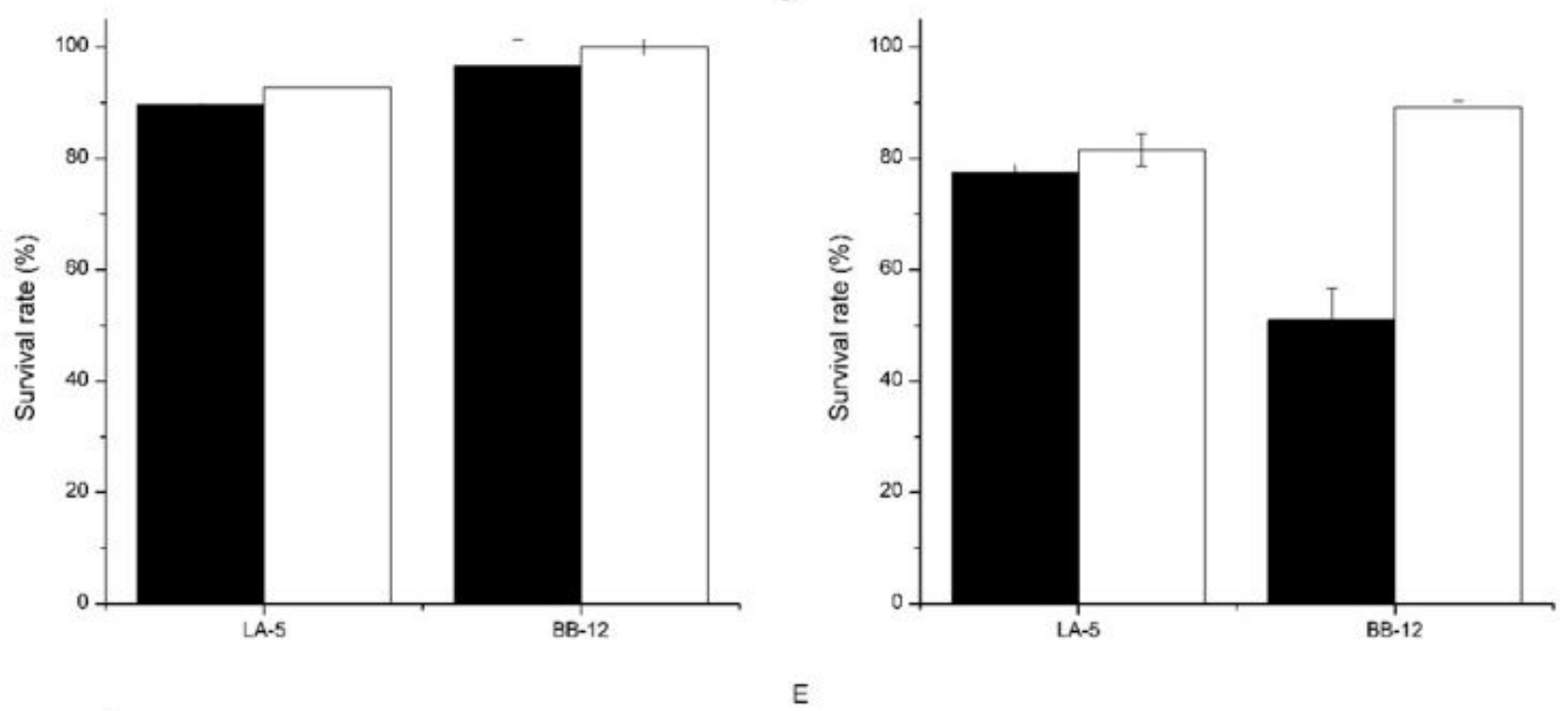

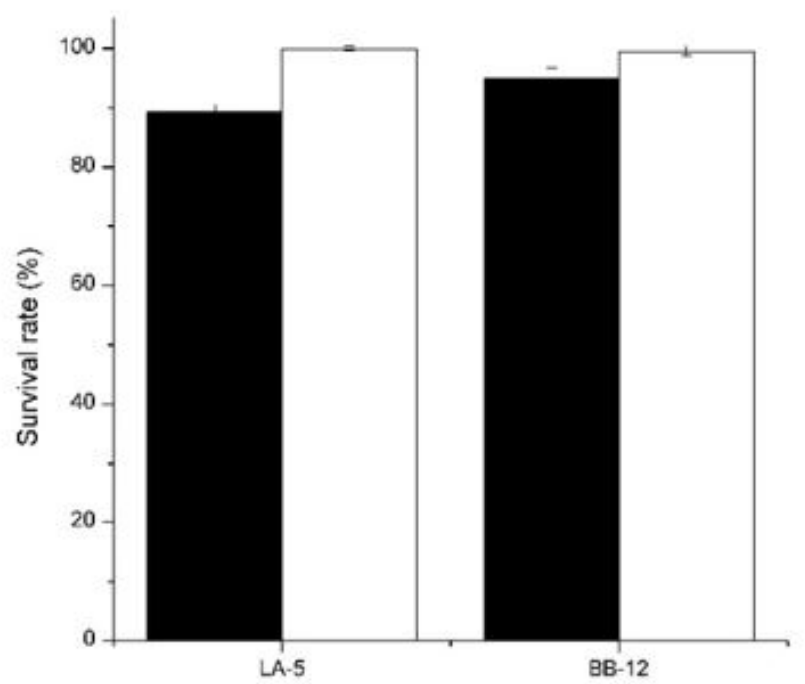

Figure 2. Survival rates (\%) of encapsulated (black bars) and free (white bars) LA-5 and BB-12 encapsulated with ricotta whey supplemented with 7:3 and 9:1 (w/w) of gelatin:collagen, respectively, after going through simulated gastric and intestinal tracts under the following conditions: (A) $\mathrm{pH} 2$; (B) $\mathrm{pH} 2.5$; (C) $\mathrm{pH} 3$; (D) with bile salts; and (E) without bile salts. 
Once they reach intestinal environment and capsules are dissolved, stressed bacteria are more likely to be affected by bile salts, since the non-encapsulated ones have higher survival rates in these conditions. We have observed this outcome in the results of this study as well as in others published by our research group (Eckert et al., 2017; Rama et al., 2020).

Liao et al. (2017) encapsulated L. casei LK-1 via SD using maltodextrin, trealose, and skimmed milk as encapsulating agents, and evaluated the survival of this microorganism under simulated GIT. There was a more pronounced reduction in viability of $L$. casei encapsulated with trealose and maltodextrin, while skimmed milk provided higher protection to lactic bacteria, thus emphasizing the potential of lactic proteins for the encapsulation of probiotics. Similarly, de Andrade et al. (2019) evaluated the survival of SD-encapsulated Lactobacillus species under simulated GIT conditions, using cheese whey as wall material. These authors observed, as did Liao et al. (2017), that reduction in cell concentrations of free bacteria was more significant under gastric and intestinal tract conditions compared to encapsulated bacteria.

In addition, it is worth noting that cell viability has been considered an essential condition for the delivery of the benefits associated to probiotic incorporation in food products so far. However, Barros et al. (2020) shows that many of the advantages related to probiotics are not linked to active cells at all. In fact, these authors state that non-viable cells, microbial parts, or cell debris could also promote health benefits for consumers. Therefore, viability may not always be the most important aspect in terms incorporating probiotic bacteria in food products. As projective tests, further sensory studies based on innovative methods of consumer perception must be conducted in order to evaluate the impacts of the addition of these microorganisms in food (Chetachukwu et al., 2019; Judacewski et al., 2019; Pinto et al., 2018; Soares et al., 2020).

\section{Conclusion}

Ricotta whey associated to gelatin and hydrolyzed collagen provided protection to L. acidophilus LA-5 and B. lactis BB-12 under the adverse conditions of SD encapsulation. During the storage period of 30 days at $25^{\circ} \mathrm{C}$, the encapsulating agents were also capable of maintaining the viability of both microorganisms. When going through simulated gastric and intestinal tract conditions, the encapsulation of microorganims with ricotta whey associated to gelatin and hydrolyzed collagen provided significant protection, especially under gastric conditions of low $\mathrm{pH}$ and presence of pepsin, under which survival rates of both LA-5 and BB-12 were higher than those of non-encapsulated microorganisms. The presence of bile salts, however, was damaging to the survival of both encapsulated bacteria, which had viabilities similar to those of free microorganisms. Therefore, the major advantage of using ricotta whey to encapsulate probiotics is its very low cost (zero cost, when considering that it is a residue of the dairy industry), and the fact that the disposal of such a pollutant waste in the environment is prevented. It is a suitable material to be used as encapsulating agent, especially because of its stability during storage and resistance to acidic environment. The disadvantage, however, is that ricotta whey, combined with gelatin and collagen, did not provide enough protection against the stresses caused by SD, which led to major loss in viability when in the presence of bile salts. Therefore, further studies aiming at applying these materials for encapsulating probiotic bacteria are required in order to maximize their use at an industrial scale.

\section{Acknowledgements}

We are grateful to Conselho Nacional de Desenvolvimento Científico e Tecnológico (CNPq) for providing the scholarship [Grant: 311655/2017-3]. We also thank Universidade do Vale do Taquari - Univates for their financial support.

\section{References}

Abd El-Salam, M. H., \& El-Shibiny, S. (2015). Preparation and properties of milk proteins-based encapsulated probiotics: a review. Dairy Science \& Technology, 95(4), 393-412. http://dx.doi.org/10.1007/ s13594-015-0223-8.

Ahmad, T., Aadil, R. M., Ahmed, H., Rahman, U., Soares, B. C. V., Souza, S. L. Q., Pimentel, T. C., Scudino, H., Guimarães, J. T., Esmerino, E. A., Freitas, M. Q., Almada, R. B., Vendramel, S. M. R., Silva, M. C., \& Cruz, A. G. (2019). Treatment and utilization of dairy industrial waste: a review. Trends in Food Science \& Technology, 88, 361-372. http://dx.doi.org/10.1016/j.tifs.2019.04.003.

Alizadeh Khaledabad, M., Ghasempour, Z., Moghaddas Kia, E., Rezazad Bari, M., \& Zarrin, R. (2020). Probiotic yoghurt functionalised with microalgae and Zedo gum: chemical, microbiological, rheological and sensory characteristics. International Journal of Dairy Technology, 73(1), 67-75. http://dx.doi.org/10.1111/1471-0307.12625.

Ananta, E., Volkert, M., \& Knorr, D. (2005). Cellular injuries and storage stability of spray-dried Lactobacillus rhamnosus GG. International Dairy Journal, 15(4), 399-409. http://dx.doi.org/10.1016/j. idairyj.2004.08.004.

Andrade, D. P., Ramos, C. L., Botrel, D. A., Borges, S. V., Schwan, R. F., \& Ribeiro Dias, D. (2019). Stability of microencapsulated lactic acid bacteria under acidic and bile juice conditions. International Journal of Food Science \& Technology, 54(7), 2355-2362. http:// dx.doi.org/10.1111/ijfs.14114.

Association of Official Analytical Chemists - AOAC. (2012). Official methods of analysis of the Association of Official Analytical Chemists (19th ed.). Arlington: AOAC. Retrieved from https://www.worldcat. org/title/official-methods-of-analysis-of-aoac-international/ oclc/817542290

Bao, Y., Zhang, Y., Zhang, Y., Liu, Y., Wang, S., Dong, X., Wang, Y., \& Zhang, H. (2010). Screening of potential probiotic properties of Lactobacillus fermentum isolated from traditional dairy products. Food Control, 21(5), 695-701. http://dx.doi.org/10.1016/j.foodcont.2009.10.010.

Barros, C. P., Guimarães, J. T., Esmerino, E. A., Duarte, M. C. K., Silva, M. C., Silva, R., Ferreira, B. M., Sant'Ana, A. S., Freitas, M. Q., \& Cruz, A. G. (2020). Paraprobiotics and postbiotics: concepts and potential applications in dairy products. Current Opinion in Food Science, 32, 1-8. http://dx.doi.org/10.1016/j.cofs.2019.12.003.

Bodewes, F. A. J. A., Wouthuyzen-Bakker, M., \& Verkade, H. J. (2015). Persistent fat malabsorption in cystic fibrosis. In R. R. Watson (Ed.), Diet and exercise in cystic fibrosis (pp. 373-381). USA: Elsevier Ltd. http://dx.doi.org/10.1016/B978-0-12-800051-9.00041-9

Brinques, G. B., do Carmo Peralba, M., \& Ayub, M. A. (2010). Optimization of probiotic and lactic acid production by Lactobacillus plantarum in submerged bioreactor systems. Journal of Industrial Microbiology \& Biotechnology, 37(2), 205-212. http://dx.doi. org/10.1007/s10295-009-0665-1. PMid:19936814. 
Bruno, M. J. (2012). Palliation of malignant pancreaticobiliary obstruction. In G. G. Ginsberg, C. J. Gostout, M. L. Kochman \& I. D. Norton (Eds.), Clinical gastrointestinal endoscopy (pp. 706-720). USA: Elsevier Ltd. http://dx.doi.org/10.1016/B978-1-4377-1529-3.00051-8

Bustos, P., \& Bórquez, R. (2013). Influence of osmotic stress and encapsulating materials on the stability of autochthonous lactobacillus plantarum after spray drying. Drying Technology, 31(1), 57-66. http:// dx.doi.org/10.1080/07373937.2012.717325.

Carvalho, F., Prazeres, A. R., \& Rivas, J. (2013). Cheese whey wastewater: characterization and treatment. The Science of the Total Environment, 445-446, 385-396. http://dx.doi.org/10.1016/j.scitotenv.2012.12.038. PMid:23376111.

Ceja-Medina, L. I., Ortiz-Basurto, R. I., Medina-Torres, L., Calderas, F., Bernad-Bernad, M. J., González-Laredo, R. F., Ragazzo-Sánchez, J. A., Calderón-Santoyo, M., González-ávila, M., Andrade-González, I., \& Manero, O. (2020). Microencapsulation of Lactobacillus plantarum by spray drying with mixtures of Aloe vera mucilage and agave fructans as wall materials. Journal of Food Process Engineering, 13436. http://dx.doi.org/10.1111/jfpe.13436.

Chetachukwu, A. S., Thongraung, C., \& Yupanqui, C. T. (2019). Development of reduced-fat coconut yoghurt: physicochemical, rheological, microstructural and sensory properties. International Journal of Dairy Technology, 72(4), 524-535. http://dx.doi. org/10.1111/1471-0307.12600.

Chugh, B., \& Kamal-Eldin, A. (2020). Bioactive compounds produced by probiotics in food products. Current Opinion in Food Science, 32, pp. 76-82. http://dx.doi.org/10.1016/j.cofs.2020.02.003.

De Castro-Cislaghi, F. P., Silva, C. D. R. E., Fritzen-Freire, C. B., Lorenz, J. G., \& Sant'Anna, E. S. (2012). Bifidobacterium Bb-12 microencapsulated by spray drying with whey: survival under simulated gastrointestinal conditions, tolerance to $\mathrm{NaCl}$, and viability during storage. Journal of Food Engineering, 113(2), 186-193. http://dx.doi.org/10.1016/j. jfoodeng.2012.06.006.

De Prisco, A., Maresca, D., Ongeng, D., \& Mauriello, G. (2015). Microencapsulation by vibrating technology of the probiotic strain Lactobacillus reuteri DSM 17938 to enhance its survival in foods and in gastrointestinal environment. Lebensmittel-Wissenschaft + Technologie, 61(2), 452-462. http://dx.doi.org/10.1016/j.lwt.2014.12.011.

Del Piano, M., Carmagnola, S., Ballarè, M., Sartori, M., Orsello, M., Balzarini, M., Pagliarulo, M., Tari, R., Anderloni, A., Strozzi, G. P., Mogna, L., Sforza, F., \& Capurso, L. (2011). Is microencapsulation the future of probiotic preparations? The increased efficacy of gastro-protected probiotics. Gut Microbes, 2(2), 120-123. http:// dx.doi.org/10.4161/gmic.2.2.15784. PMid:21637030.

Dianawati, D., Mishra, V., \& Shah, N. P. (2013). Survival of Bifidobacterium longum 1941 microencapsulated with proteins and sugars after freezing and freeze drying. Food Research International, 51(2), 503509. http://dx.doi.org/10.1016/j.foodres.2013.01.022.

Ding, W. K., \& Shah, N. P. (2007). Acid, bile, and heat tolerance of free and microencapsulated probiotic bacteria. Journal of Food Science, 72(9), M446-M450. http://dx.doi.org/10.1111/j.1750-3841.2007.00565.x. PMid:18034741.

Ding, W. K., \& Shah, N. P. (2009). An improved method of microencapsulation of probiotic bacteria for their stability in acidic and bile conditions during storage. Journal of Food Science, 74(2), M53-M61. http:// dx.doi.org/10.1111/j.1750-3841.2008.01030.x. PMid:19323758.

Đorđević, V., Balanč, B., Belščak-Cvitanović, A., Lević, S., Trifković, K., Kalušević, A., Kostić, I., Komes, D., Bugarski, B., \& Nedović, V. (2014). Trends in encapsulation technologies for delivery of food bioactive compounds. Food Engineering Reviews, 7(4), 452-490. http://dx.doi.org/10.1007/s12393-014-9106-7.
Eckert, C., Agnol, W. D., Dallé, D., Serpa, V. G., Maciel, M. J., Lehn, D. N., \& Volken de Souza, C. F. (2018). Development of alginate-pectin microparticles with dairy whey using vibration technology: Effects of matrix composition on the protection of Lactobacillus spp. from adverse conditions. Food Research International, 113, 65-73. http:// dx.doi.org/10.1016/j.foodres.2018.07.001. PMid:30195547.

Eckert, C., Serpa, V. G., Felipe dos Santos, A. C., Marinês da Costa, S., Dalpubel, V., Lehn, D. N., \& Volken de Souza, C. F. (2017). Microencapsulation of Lactobacillus plantarum ATCC 8014 through spray drying and using dairy whey as wall materials. Lebensmittel-Wissenschaft + Technologie, 82, 176-183. http://dx.doi.org/10.1016/j.lwt.2017.04.045.

Euston, S. R., Baird, W. G., Campbell, L., \& Kuhns, M. (2013). Competitive adsorption of dihydroxy and trihydroxy bile salts with whey protein and casein in oil-in-water emulsions. Biomacromolecules, 14(6), 1850-1858. http://dx.doi.org/10.1021/bm4002443. PMid:23617462.

Fangmeier, M., Kemerich, G. T., MacHado, B. L., Maciel, M. J., \& Souza, C. F. V. (2019). Effects of cow, goat, and buffalo milk on the characteristics of cream cheese with whey retention. Food Science and Technology (Campinas), 39(suppl 1), 122-128. http://dx.doi.org/10.1590/fst.39317.

Fernández, M., Hudson, J. A., Korpela, R., \& de los Reyes-Gavilán, C. G. (2015). Impact on human health of microorganisms present in fermented dairy products: an overview. BioMed Research International, 2015, 412714. http://dx.doi.org/10.1155/2015/412714. PMid:25839033.

Ferrando, V., Quiberoni, A., Reinheimer, J., \& Suárez, V. (2016). Functional properties of Lactobacillus plantarum strains: a study in vitro of heat stress influence. Food Microbiology, 54, 154-161. http://dx.doi.org/10.1016/j.fm.2015.10.003.

Food and Agriculture Organization - FAO \& World Health Organization - WHO. (2002). Guidelines for the evaluation of probiotics in food. In Food and Agriculture Organization - FAO \& World Health Organization - WHO. Guidelines for the evaluation of probiotics in food. Report of a Joint FAO/WHO Working Group on Drafting Guidelines for the Evaluation of Probiotics in Food. Rome: FAO.

Fox, P. F., Uniacke-Lowe, T., McSweeney, P. L. H., \& O’Mahony, J. A. (2015). Heat-Induced Changes in Milk. In P. F. Fox, T. Uniacke-Lowe, P. L. H. McSweeney \& J. A. O’Mahony (Eds.), Dairy Chemistry and Biochemistry (pp. 345-375). Springer International Publishing. http://dx.doi.org/10.1007/978-3-319-14892-2_9

Gbassi, G. K., Vandamme, T., Ennahar, S., \& Marchioni, E. (2009). Microencapsulation of Lactobacillus plantarum spp in an alginate matrix coated with whey proteins. International Journal of Food Microbiology, 129(1), 103-105. http://dx.doi.org/10.1016/j. ijfoodmicro.2008.11.012. PMid:19059666.

Golowczyc, M. A., Silva, J., Teixeira, P., De Antoni, G. L., \& Abraham, A. G. (2011). Cellular injuries of spray-dried Lactobacillus spp. isolated from kefir and their impact on probiotic properties. International Journal of Food Microbiology, 144(3), 556-560. http:// dx.doi.org/10.1016/j.ijfoodmicro.2010.11.005. PMid:21144610.

Gómez-Guillén, M. C., Giménez, B., López-Caballero, M. E., \& Montero, M. P. (2011). Functional and bioactive properties of collagen and gelatin from alternative sources: A review. Food Hydrocolloids, 25(8), 1813-1827. http://dx.doi.org/10.1016/j.foodhyd.2011.02.007.

Gong, P., Zhang, L., Han, X., Shigwedha, N., Song, W., Yi, H., Du, M., \& Cao, C. (2014). Injury mechanisms of lactic acid bacteria starter cultures during spray drying: a review. Drying Technology, 32(7), 793-800. http://dx.doi.org/10.1080/07373937.2013.860458.

Guergoletto, K. B., Busanello, M., \& Garcia, S. (2017). Influence of carrier agents on the survival of Lactobacillus reuteri LR92 and the physicochemical properties of fermented juçara pulp produced by spray drying. $L W T, 80,321-327$. http://dx.doi.org/10.1016/j. lwt.2017.02.038. 
Guimarães, J. T., Balthazar, C. F., Silva, R., Rocha, R. S., Graça, J. S., Esmerino, E. A., Silva, M. C., Sant'Ana, A. S., Duarte, M. C. K. H., Freitas, M. Q., \& Cruz, A. G. (2020). Impact of probiotics and prebiotics on food texture. Current Opinion in Food Science, 33, 38-44. http://dx.doi.org/10.1016/j.cofs.2019.12.002.

Guimarães, J. T., Silva, E. K., Alvarenga, V. O., Costa, A. L. R., Cunha, R. L., Sant'Ana, A. S., Freitas, M. Q., Meireles, M. A. A., \& Cruz, A. G. (2018). Physicochemical changes and microbial inactivation after high-intensity ultrasound processing of prebiotic whey beverage applying different ultrasonic power levels. Ultrasonics Sonochemistry, 44, 251-260. http://dx.doi.org/10.1016/j.ultsonch.2018.02.012. PMid:29680610.

Guimarães, J. T., Silva, E. K., Ranadheera, C. S., Moraes, J., Raices, R. S. L., Silva, M. C., Ferreira, M. S., Freitas, M. Q., Meireles, M. A. A., \& Cruz, A. G. (2019). Effect of high-intensity ultrasound on the nutritional profile and volatile compounds of a prebiotic soursop whey beverage. Ultrasonics Sonochemistry, 55, 157-164. http://dx.doi. org/10.1016/j.ultsonch.2019.02.025. PMid:30853535.

Guimarães, P. M. R., Teixeira, J. A., \& Domingues, L. (2010). Fermentation of lactose to bio-ethanol by yeasts as part of integrated solutions for the valorisation of cheese whey. Biotechnology Advances, 28(3), 375-384. http://dx.doi.org/10.1016/j.biotechadv.2010.02.002. PMid:20153415.

Huang, S., Gaucher, F., Cauty, C., Jardin, J., Le Loir, Y., Jeantet, R., Chen, X. D., \& Jan, G. (2018). Growth in hyper-concentrated sweet whey triggers multi stress tolerance and spray drying survival in lactobacillus casei BL23: from the molecular basis to new perspectives for sustainable probiotic production. Frontiers in Microbiology, 9, 2548. http://dx.doi.org/10.3389/fmicb.2018.02548. PMid:30405593.

Huang, S., Méjean, S., Rabah, H., Dolivet, A., Le Loir, Y., Chen, X. D., Jan, G., Jeantet, R., \& Schuck, P. (2017). Double use of concentrated sweet whey for growth and spray drying of probiotics: towards maximal viability in pilot scale spray dryer. Journal of Food Engineering, 196, 11-17. http://dx.doi.org/10.1016/j.jfoodeng.2016.10.017.

Ilha, E. C., da Silva, T., Lorenz, J. G., de Oliveira Rocha, G., \& Sant'Anna, E. S. (2015). Lactobacillus paracasei isolated from grape sourdough: acid, bile, salt, and heat tolerance after spray drying with skim milk and cheese whey. European Food Research and Technology, 240(5), 977-984. http://dx.doi.org/10.1007/s00217-014-2402-x.

Islam, M. I. U., Edrisi, M., \& Langrish, T. (2013). Improving Process Yield by Adding WPI to Lactose During Crystallization and Spray Drying Under High-Humidity Conditions. Drying Technology, 31(4), 393-404. http://dx.doi.org/10.1080/07373937.2012.737396.

Judacewski, P., Los, P. R., Lima, L. S., Alberti, A., Zielinski, A. A. F., \& Nogueira, A. (2019). Perceptions of Brazilian consumers regarding white mould surface-ripened cheese using free word association. International Journal of Dairy Technology, 72(4), 585590. http://dx.doi.org/10.1111/1471-0307.12649.

Khem, S., Bansal, V., Small, D. M., \& May, B. K. (2016a). Comparative influence of $\mathrm{pH}$ and heat on whey protein isolate in protecting Lactobacillus plantarum A17 during spray drying. Food Hydrocolloids, 54, 162-169. http://dx.doi.org/10.1016/j.foodhyd.2015.09.029.

Khem, S., Small, D. M., \& May, B. K. (2016b). The behaviour of whey protein isolate in protecting Lactobacillus plantarum. Food Chemistry, 190, 717-723. http://dx.doi.org/10.1016/j.foodchem.2015.06.020. PMid:26213030.

Khorshidian, N., Yousefi, M., Shadnoush, M., Siadat, S. D., Mohammadi, M., \& Mortazavian, A. M. (2020). Using probiotics for mitigation of acrylamide in food products: a mini review. Current Opinion in Food Science, 32, 67-75. http://dx.doi.org/10.1016/j.cofs.2020.01.011.

Kim, S.-J., Cho, S. Y., Kim, S. H., Song, O.-J., Shin, I.-S., Cha, D. S., \& Park, H. J. (2008). Effect of microencapsulation on viability and other characteristics in Lactobacillus acidophilus ATCC 43121. Lebensmittel-Wissenschaft + Technologie, 41(3), 493-500. http:// dx.doi.org/10.1016/j.lwt.2007.03.025.

Knorr Valadão, N., Morais Geremias De Andrade, I., Jory, J. C., Gallo, F. A., \& Petrus, R. R. (2016). Development of a ricotta cheese whey-based sports drink. Journal Advances in Dairy Research, 4(3), 1000156. https://doi.org/10.4172/2329-888X.1000156.

Lavari, L., Ianniello, R., Páez, R., Zotta, T., Cuatrin, A., Reinheimer, J., Parente, E., \& Vinderola, G. (2015). Growth of Lactobacillus rhamnosus 64 in whey permeate and study of the effect of mild stresses on survival to spray drying. Lebensmittel-Wissenschaft + Technologie, 63(1), 322-330. http://dx.doi.org/10.1016/j.lwt.2015.03.066.

Li, L., \& Han, N. S. (2018). Application of lactic acid bacteria for food biotechnology. In H. N. Chang (Ed.), Emerging areas in bioengineering (pp. 375-398). London: Wiley-VCH Verlag GmbH \& Co. http:// dx.doi.org/10.1002/9783527803293.ch22.

Li, X. Y., Chen, X. G., Cha, D. S., Park, H. J., \& Liu, C. S. (2009). Microencapsulation of a probiotic bacteria with alginate-gelatin and its properties. Journal of Microencapsulation, 26(4), 315-324. http://dx.doi.org/10.1080/02652040802328685. PMid:18668418.

Liao, L. K., Wei, X. Y., Gong, X., Li, J. H., Huang, T., \& Xiong, T. (2017). Microencapsulation of Lactobacillus casei LK-1 by spray drying related to its stability and in vitro digestion. Lebensmittel-Wissenschaft + Technologie, 82, 82-89. http://dx.doi.org/10.1016/j.lwt.2017.03.065.

Lucatto, J. N., Silva-Buzanello, R. A., Mendonça, S. N. T. G., Lazarotto, T. C., Sanchez, J. L., Bona, E., \& Drunkler, D. A. (2020). Performance of different microbial cultures in potentially probiotic and prebiotic yoghurts from cow and goat milks. International Journal of Dairy Technology, 73(1), 144-156. http://dx.doi.org/10.1111/1471-0307.12655.

Maciel, G. M., Chaves, K. S., Grosso, C. R. F., \& Gigante, M. L. (2014). Microencapsulation of Lactobacillus acidophilus La- 5 by spraydrying using sweet whey and skim milk as encapsulating materials. Journal of Dairy Science, 97(4), 1991-1998. http://dx.doi.org/10.3168/ jds.2013-7463. PMid:24508439.

Maldonado-Valderrama, J., Wilde, P., MacIerzanka, A., \& MacKie, A. (2011). The role of bile salts in digestion. Advances in Colloid and Interface Science, 165(1), 36-46. http://dx.doi.org/10.1016/j. cis.2010.12.002. PMid:21236400.

Meira, S. M. M., Helfer, V. E., Velho, R. V., Lopes, F. C., \& Brandelli, A. (2012). Probiotic potential of Lactobacillus spp. isolated from Brazilian regional ovine cheese. The Journal of Dairy Research, 79(1), 119-127. http://dx.doi.org/10.1017/S0022029911000884. PMid:23171587.

Miller, G. L. (1959). Use of dinitrosalicylic acid reagent for determination of reducing sugar. Analytical Chemistry, 31(3), 426-428. http://dx.doi. org/10.1021/ac60147a030.

Mollea, C., Marmo, L., \& Bosco, F. (2013). Valorisation of cheese whey, a by-product from the dairy industry. Food Industries. http://dx.doi. org/10.5772/53159.

Monteiro, S. H. M. C., Silva, E. K., Alvarenga, V. O., Moraes, J., Freitas, M. Q., Silva, M. C., Raices, R. S. L., Sant'Ana, A. S., Meireles, M. A. A., \& Cruz, A. G. (2018). Effects of ultrasound energy density on the non-thermal pasteurization of chocolate milk beverage. Ultrasonics Sonochemistry, 42, 1-10. http://dx.doi.org/10.1016/j. ultsonch.2017.11.015. PMid:29429649.

Monteiro, S. H. M. C., Silva, E. K., Guimarães, J. T., Freitas, M. Q., Meireles, M. A. A., \& Cruz, A. G. (2020). High-intensity ultrasound energy density: how different modes of application influence the quality parameters of a dairy beverage. Ultrasonics Sonochemistry, 63, 104928. http://dx.doi.org/10.1016/j.ultsonch.2019.104928. PMid:31952002. 
Motta, A. D. S., \& Gomes, M. D. S. M. (2015). Technological and functional properties of lactic acid bacteria: the importanceof these microorganisms for food. Revista do Instituto de Latícinios Cândido Tostes, 70(3), 172. http://dx.doi.org/10.14295/2238-6416.v70i3.403.

Nunes, G. L., Motta, M. H., Cichoski, A. J., Wagner, R., Muller, É. I., Codevilla, C. F., Silva, C. B., \& Menezes, C. R. (2018). Encapsulation of lactobacillus acidophilus la- 5 and bifidobacterium bb- 12 by spray drying and evaluation of its resistance in simulated gastrointestinal conditions, thermal treatments and storage conditions. Ciência Rural, 48(6), 1-11. http://dx.doi.org/10.1590/0103-8478cr20180035.

Oluwaseun Sunny-Roberts, E. O., \& Knorr, D. (2011). Cellular injuries on spray-dried Lactobacillus rhamnosus GG and its stability during food storage. Nutrition \& Food Science, 41(3), 191-200. http://dx.doi. org/10.1108/00346651111132466.

Peighambardoust, S. H., Golshan Tafti, A., \& Hesari, J. (2011). Application of spray drying for preservation of lactic acid starter cultures: a review. Trends in Food Science \& Technology, 22(5), 215-224. http:// dx.doi.org/10.1016/j.tifs.2011.01.009.

Pérez-Chabela, M. L., Lara-Labastida, R., Rodriguez-Huezo, E., \& Totosaus, A. (2013). Effect of Spray Drying Encapsulation of Thermotolerant Lactic Acid Bacteria on Meat Batters Properties. Food and Bioprocess Technology, 6(6), 1505-1515. http://dx.doi. org/10.1007/s11947-012-0865-y.

Picot, A., \& Lacroix, C. (2004). Encapsulation of bifidobacteria in whey protein-based microcapsules and survival in simulated gastrointestinal conditions and in yoghurt. International Dairy Journal, 14(6), 505515. http://dx.doi.org/10.1016/j.idairyj.2003.10.008.

Pinto, L. P. F., Silva, H. L. A., Kuriya, S. P., Maçaira, P. M., Cyrino Oliveira, F. L., Cruz, A. G., Esmerino, E. A., \& Freitas, M. Q. (2018). Understanding perceptions and beliefs about different types of fermented milks through the application of projective techniques: A case study using Haire's shopping list and free word association. Journal of Sensory Studies, 33(3), e12326. http://dx.doi.org/10.1111/joss.12326.

Prasanna, P. H. P., \& Charalampopoulos, D. (2018). Encapsulation of Bifidobacterium longum in alginate-dairy matrices and survival in simulated gastrointestinal conditions, refrigeration, cow milk and goat milk. Food Bioscience, 21, 72-79. http://dx.doi.org/10.1016/j.fbio.2017.12.002.

Puupponen-Pimiä, R., Aura, A. M., Oksman-Caldentey, K. M., Myllärinen, P., Saarela, M., Mattila-Sandholm, T., \& Poutanen, K. (2002). Development of functional ingredients for gut health. Trends in Food Science \& Technology, 13(1), 3-11. http://dx.doi.org/10.1016/ S0924-2244(02)00020-1.

Rama, G. R., Führ, A. J., da Silva, J. A. B. S., Gennari, A., Giroldi, M., Goettert, M. I., \& Volken de Souza, C. F. (2020). Encapsulation of Lactobacillus spp. using bovine and buffalo cheese whey and their application in orange juice. 3 Biotech, 10(6), 1-13. https://doi. org/10.1007/s13205-020-02255-9.

Rama, G. R., Kuhn, D., Beux, S., Maciel, M. J., \& Volken de Souza, C. F. (2019). Potential applications of dairy whey for the production of lactic acid bacteria cultures. International Dairy Journal, 98, 25-37. http://dx.doi.org/10.1016/j.idairyj.2019.06.012.

Ranadheera, C. S., Evans, C. A., Adams, M. C., \& Baines, S. K. (2015). Microencapsulation of Lactobacillus acidophilus LA-5, Bifidobacterium animalis subsp. lactis BB-12 and Propionibacterium jensenii 702 by spray drying in goat's milk. Small Ruminant Research, 123(1), 155-159. http://dx.doi.org/10.1016/j.smallrumres.2014.10.012.

Rokka, S., \& Rantamäki, P. (2010). Protecting probiotic bacteria by microencapsulation: challenges for industrial applications. European
Food Research and Technology, 231(1), 1-12. http://dx.doi.org/10.1007/ s00217-010-1246-2.

Roobab, U., Batool, Z., Manzoor, M. F., Shabbir, M. A., Khan, M. R., \& Aadil, R. M. (2020). Sources, formulations, advanced delivery and health benefits of probiotics. Current Opinion in Food Science, 32, 17-28. http://dx.doi.org/10.1016/j.cofs.2020.01.003.

Salar-Behzadi, S., Wu, S., Toegel, S., Hofrichter, M., Altenburger, I., Unger, F. M., Wirth, M., \& Viernstein, H. (2013). Impact of heat treatment and spray drying on cellular properties and culturability of Bifidobacterium bifidum BB-12. Food Research International, 54(1), 93-101. http://dx.doi.org/10.1016/j.foodres.2013.05.024.

Sannasiddappa, T. H., Lund, P. A., \& Clarke, S. R. (2017). In vitro antibacterial activity of unconjugated and conjugated bile salts on staphylococcus aureus. Frontiers in Microbiology, 8, 1581. http:// dx.doi.org/10.3389/fmicb.2017.01581. PMid:28878747.

Sansonetti, S., Curcio, S., Calabrò, V., \& Iorio, G. (2009). Bio-ethanol production by fermentation of ricotta cheese whey as an effective alternative non-vegetable source. Biomass and Bioenergy, 33(12), 1687-1692. http://dx.doi.org/10.1016/j.biombioe.2009.09.002.

Santivarangkna, C., Higl, B., \& Foerst, P. (2008a). Protection mechanisms of sugars during different stages of preparation process of dried lactic acid starter cultures. Food Microbiology, 25(3), 429-441. http:// dx.doi.org/10.1016/j.fm.2007.12.004. PMid:18355668.

Santivarangkna, C., Kulozik, U., \& Foerst, P. (2008b). Inactivation mechanisms of lactic acid starter cultures preserved by drying processes. Journal of Applied Microbiology, 105(1), 1-13. http:// dx.doi.org/10.1111/j.1365-2672.2008.03744.x. PMid:18266696.

Sarfraz, F., Farooq, U., Shafi, A., Hayat, Z., Akram, K., \& Rehman, H. (2019). Hypolipidaemic effects of synbiotic yoghurt in rabbits. International Journal of Dairy Technology, 72(4), 545-550. http:// dx.doi.org/10.1111/1471-0307.12618.

Shafi, A., Raja, H. N., Farooq, U., Akram, K., Hayat, Z., \& Naz, A. (2019). Antimicrobial and antidiabetic potential of synbiotic fermented milk: a functional dairy product. International Journal of Dairy Technology, 72(1), 15-22. https://doi.org/10.1111/1471-0307.12555.

Smithers, G. W. (2015). Whey-ing up the options - Yesterday, today and tomorrow. International Dairy Journal, 48, 2-14. http://dx.doi. org/10.1016/j.idairyj.2015.01.011.

Soares, E. K. B., Silva, R., Silva, W. P., Kuriya, S. P., Maçaira, P. M., Cyrino Oliveira, F. L., Silva, M. A. A. P., Pimentel, T. C., Freitas, M. Q., Cruz, A. G., \& Esmerino, E. A. (2020). An intra-cultural investigation in Brazil using Coalho cheese and preferred attribute elicitation. Journal of Sensory Studies, 35(1). http://dx.doi.org/10.1111/joss.12543.

Trindade, M. B., Soares, B. C. V., Scudino, H., Guimarães, J. T., Esmerino, E. A., Freitas, M. Q., Pimentel, T. C., Silva, M. C., Souza, S. L. Q., Almada, R. B., \& Cruz, A. G. (2019). Cheese whey exploitation in Brazil: A questionnaire survey. Food Science and Technology (Campinas), 39(3), 788-791. http://dx.doi.org/10.1590/fst.07419.

Tripathi, M. K., \& Giri, S. K. (2014). Probiotic functional foods: Survival of probiotics during processing and storage. Journal of Functional Foods, 9, 225-241. http://dx.doi.org/10.1016/j.jff.2014.04.030.

Wang, Y., Zhang, W., Yuan, J., \& Shen, J. (2016). Differences in cytocompatibility between collagen, gelatin and keratin. Materials Science and Engineering $C$, 59, 30-34. http://dx.doi.org/10.1016/j.msec.2015.09.093. PMid:26652345.

Zendeboodi, F., Khorshidian, N., Mortazavian, A. M., \& da Cruz, A. G. (2020). Probiotic: conceptualization from a new approach. Current Opinion in Food Science, 32, 103-123. http://dx.doi.org/10.1016/j. cofs.2020.03.009. 